\title{
Genetic Variability for Quantitative and Qualitative Characters in Brinjal (Solanum melongena L.)
}

\author{
Jyoti P. Jirankali*, Nikhila Reddy, S. Gangaprasad and S.N. Manohara \\ Department of Genetics and Plant breeding, College of Agriculture, \\ UAHS, Shivamogga -577216 , India \\ *Corresponding author
}

\section{A B S T R A C T}

Keywords

Brinjal, Genotypic coefficient of variation,

Phenotypic coefficient of variation, Solanum melongena, Fruit borer infestation

Article Info

Accepted:

07 February 2019

Available Online:

10 March 2019
In brinjal, lower marketable yield could be attributed to susceptibility of genotypes to shoot and fruit borer. The present investigation in brinjal (Solanum melongena L.) was undertaken during kharif season of 2016 for high marketable yield and fruit borer resistance. Hundred brinjal genotypes along with two checks were evaluated in Augmented design in University of Horticultural and Agricultural Sciences, Shivamogga. Analysis of variance revealed high significant differences among genotypes for fifteen out of nineteen characters studied. High estimates of PCV, GCV, heritability coupled with high genetic advance were observed for fruit weight, number of fruits per cluster and shoot borer infestation. Hence indicating high variability for these traits and selection for these traits may be effective.

\section{Introduction}

India, being the primary centre of origin has accumulated wide range of variation in this crop. A great genetic variation with regard to colour, maturity, fruit shape, vegetative characters and spinyness of the plants exists among the indigenous material. The wide range of variability was observed in respect of morphological traits. The genetic variance of any quantitative trait is composed of additive variance (heritable) and non-additive variance (non-heritable). Therefore, it becomes necessary to partition the observed phenotypic variability into its genotypic (partly heritable) and environmental (non-heritable) components with suitable parameters, such as phenotypic and genotypic coefficient of variation and heritability in broad sense. Effectiveness of selection directly depends on the amount of heritability and genetic advance as per cent mean of the character. Thus, the 
improvement in yield is possible only through selection of the desired component characters.

\section{Materials and Methods}

In the proposed research work conducted at ZAHRS Navile, Shivamogga during Kharif 2016-17, among the local germplasm collected from Organic forming research institute (OFRC) 100 superior germplasm lines were identified. The experiment was laid out in Augmented design, tray sowing was carried out in 6 June 2016. The seedlings were transplanted in main field 25 days after sowing with the spacing of $60 \times 45 \mathrm{cms}$ in Augmented design along with 2 checks. All the recommended cultural practices and plant protection measures were followed, observations were recorded for 100 genotypes along with 2 checks viz., leaf area, Days to first flowering, Days to 50 per cent flowering, Days to first fruit maturity, Plant height, Plant spread, No. of primary branches, Fruit length, Fruit diameter, Fruit length-diameter ratio, Fruit length of peduncle, Fruit length of calyx, Fruit length of pistil scar, No. of fruits per cluster, No. of fruits per plant, Average fruit weight, Total yield per hectar, fruit and shoot borer infestation on fruit, fruit and shoot borer infestation on shoot.

\section{Results and Discussion}

Totally 102 genotypes were evaluated to know the amount of variability for yield and yield contributing characters. The analysis of variance (Table 1) indicated highly significant differences among genotypes for most of the characters viz., plant height, plant spread, number of primary branches, days to first flowering, days to 50 per cent flowering, days to first fruit maturity, fruit length, fruit diameter, fruit length/diameter ratio, fruit size of calyx, fruit diameter of pistil scar, number of fruits per cluster, fruit weight, yield and shoot borer infestation. It indicated that sufficient variability existed for all the characters and considerable improvement could be achieved in most of these characters by selection.

One of the ways in which the variability of these characters assessed is through a simple approach of examining the range of variation. Range of variation observed for all the traits (Table 2) indicated the presence of sufficient amount of variation among the genotypes for all the characters studied. The range in the values reflects the amount of phenotypic variability which is not very reliable since it includes genotypic, environmental and genotype $\mathrm{x}$ environmental interaction components and does not reveal as which component is showing higher degree of variability.

In the present investigation, high genotypic coefficient of variation and phenotypic coefficient of variation (>20\%) were observed for leaf area and number of primary branches. Similar results were also obtained by Kumar et al., (2011), Shekar et al., (2012) and Karak et al., (2012) Lokesh et al., (2013a) and Nayak and Nagre (2013). It indicated the presence of high variability in the germplasm for selection and even the differences between PCV and GCV values were minimum, indicating that traits under study were less influenced by environment. Hence, these characters can be relied upon and simple selection can be practiced for further improvement.

Low GCV and PCV were recorded for days to 50 per cent flowering. These findings are in close agreement with the results obtained by Muniappan et al., (2010), Sao and Dahatonde et al., (2010), Kumar et al., (2011), Shekar et al., (2012) and Arunkumar et al., (2013) Das et al., (2002), Mishra et al., (2008), Sabeena et al.,(2011) and Vandana et al., (2014). Low GCV and PCV indicated the narrow genetic base therefore selection for such traits may not 
give desirable results. Moderate GCV and PCV were observed for days to first flowering and days to first fruit maturity indicating the little influence of environment. Therefore, phenotypic variability may be a good measure of genotypic variability. The findings of Ramesh et al., (2013), Abul et al., (2015) and Gavade and Ghadage (2015) are in conformity with the present findings.

High heritability coupled with moderate genetic advance as percentage over mean was recorded for days to fifty per cent flowering indicating that the expression of this character as governed by non-additive gene action and could be exploited through heterosis breeding. This view was supported by Vandana et al., (2014), Lokesh et al., (2013a) and Akpan et al., (2016).

High heritability coupled with high genetic advance as percentage over mean was recorded for days to first flowering and days to first fruit maturity indicating that the heritability is due to additive gene effects and selection may be effective. This view was supported by Sherly and Shanthi (2008), Sabeena et al., (2011) and Abul et al., (2015).

In the present study, very high heritability $(>60 \%)$ along with high genetic advance as per cent over mean $(>20 \%)$ was recorded for the growth parameters viz., plant height, plant spread number of primary branches and leaf area. These results suggested that the inheritance of such characters is governed mainly by additive gene effects and therefore, selection based on phenotypic performance may prove useful. Similar results were also reported by Muniappan et al., (2010), Karak et al.,(2012), Kumar et al., (2012), Arunkumar et al., (2013), Lokesh et al., (2013a), Vandana et al., (2014) and Akpan et al., (2016).

Moderate estimates of GCV and PCV (11$20 \%$ ) were observed for plant height and plant spread. Several workers viz., Dahatonde et al., (2010), Kumar et al., (2011), Sabeena et al.,(2011), Karak et al., (2012) and Ramesh et al., (2013), reported similar findings. These results suggest that influence of environment was low or little. Therefore, phenotypic variability may be a good measure of genotypic variability.

High (>20\%) GCV and PCV were observed for most of yield traits viz., fruit size of calyx, fruit diameter of pistil scar, fruit length, fruit diameter and fruit length-diameter ratio. These results indicated the existence of sufficient variability in genetic stock studied and the environmental role is negligible. Hence, there is ample scope for improving these characters with direct selection. Several workers like Kumar et al., (2012), Arunkumar et al., (2013), Ramesh et al., (2013), Lokesh et al., (2013), Gavade and Ghadage (2015), Nayak and Nagre (2013), Sharmin et al.,(2010), Vandana et al., (2014), Abul et al., (2015), Vidhya and Kumar (2015) and Akpan et al., (2016) reported similar findings.

High (>20\%) GCV and PCV were observed for most of yield traits viz., number of fruits per cluster, fruit weight, number of fruits per plant, and yield per hectare. These results indicated the existence of sufficient variability in genetic stock studied and the environmental role is negligible. Hence, there is ample scope for improving these characters with direct selection. Several workers like Dahatondee $t$ al., (2010), Das et al., (2010), Muniappan et al., (2010), Kumar et al., (2012), Arunkumar et al., (2013), Lokesh et al., (2013), Nayak and Nagre (2013) and Abul et al., (2015) reported similar findings.

High heritability (>60\%) estimates along with high GAM (>20\%) was recorded for number of fruits per cluster, fruit length, fruit diameter, fruit length/diameter ratio, fruit weight, yield per hectare indicating 
predominance of additive gene component. Thus, there is ample scope for improving these characters with direct selection. In the existing germplasm stock, the per se performance of genotypes M-1, N-2, MS-2 and B-2 for fruit weight and B-1, M-6, B-3 and P-2 for yield per plant indicated that these genotypes could be used for further improvement. Similar findings were also reported by several investigators like Dahatonde et al., (2010), Das et al., (2010), Muniappan et al., (2010), Kumar et al., (2012), Arunkumar et al., (2013), Lokesh et al., (2013) Ramesh et al., (2013), Vandana et al., (2014), Nayak and Nagre (2013) and Vidhya and Kumar (2015). Moderate (11-20\%) GCV and PCV were observed for fruit length of peduncle indicating presence of moderate amount of variability for these traits. Selection for such traits may not give desired results. Similar results were also obtained by Ramesh et al., (2013).

High (>20\%) GCV and PCV were observed for most of yield traits viz., fruit borer infestation (\%), shoot borer infestation (\%). These results indicated the existence of sufficient variability in genetic stock studied and the environmental role is negligible. Hence, there is ample scope for improving these characters with direct selection. Several workers like Lokesh et al., (2013a), Nayak and Nagre (2013), reported similar findings. High heritability $(>60 \%)$ estimates along with high GAM (>20\%) was recorded for fruit borer infestation (\%), shoot borer infestation $(\%)$, indicating predominance of additive gene component.

Table.1 Analysis of variance in brinjal genotypes for various quantitative traits

\begin{tabular}{|c|c|c|c|c|c|c|c|c|c|}
\hline $\begin{array}{l}\text { SL. } \\
\text { No. }\end{array}$ & Source & Tre & Checks & $\begin{array}{l}\text { Checks+Va } \\
\text { vs. Var }\end{array}$ & Block & Entries & $\mathrm{Va}$ & $\begin{array}{l}\text { Checks v } \\
\text { varieties }\end{array}$ & $\mathbf{r}$ \\
\hline & Degrees of freedom & 101 & 1 & 100 & 4 & 101 & 99 & 1 & 4 \\
\hline 1. & Leaf area $\left(\mathrm{cm}^{2}\right)$ & 1.71 & $1552.27=$ & 905.30 & 1884.1 & 983.45 & 978.19 & 935.02 & 176 \\
\hline 2. & Days $\mathrm{t}$ & $.14^{* *}$ & $9.03 *$ & $35.40 * *$ & 128.75 & 40.18 & 40.87 & 3.41 & 0.77 \\
\hline 3. & Days & $32.35 * *$ & $23.10=$ & $.45 * *$ & 112.67 & 36.78 & 36.84 & 44.44 & 0.77 \\
\hline 4. & Days & $116.91 * *$ & 929 & $8 * *$ & 560.16 & 138.73 & 130.26 & $21 *$ & 5.14 \\
\hline 5. & Plar & & 183 & & 395.93 & $91.86 *$ & & 43.35 & 10.30 \\
\hline 6. & Plar & 120 & $93.40 * *$ & $120.97 * *$ & 835.07 & $5 * *$ & $155.80 *$ & & \\
\hline 7. & Nun & $4.65 *$ & 90.0 & & 6.31 & $4.87 *$ & 3.88 & & 0.73 \\
\hline 8. & Fru & & 5.99 & & 7. & 4.7 & & 8. & 0.07 \\
\hline 9. & Fru & & 0.1 & & 1. & & & & 0. \\
\hline 10. & $F$ & & 0.1 & ** & 0. & & & 0 . & 0. \\
\hline 11. & uit & & & & 0. & 0. & & & 0 . \\
\hline 12. & uit & & 2.0 & & & & & & 0 . \\
\hline 13. & uit & 0 . & 0.2 & ** & 0 . & 0.1 & & 1. & 0.01 \\
\hline 14. & Imb & & 0. & & 0. & 0.1 & & & 0. \\
\hline 15. & I & 77 & 11 & & & 77 & & $0 *$ & 22.30 \\
\hline 16. & . & & 439 & $52 * *$ & 35 & 47( & & & 3.70 \\
\hline 17. & I & & 48991.57 & & & $.53 *$ & & & 741. \\
\hline 18. & & & 196. & & & & & & 171.1 \\
\hline 19. & Shoot & $40 *$ & $129.81^{*}$ & $119.30 *$ & 410.08 & $134.1 * *$ & $135.47=$ & 4.29 & 9.77 \\
\hline
\end{tabular}


Table.2 Estimates of genetic parameters in brinjal genotypes for various quantitative characters

\begin{tabular}{|c|c|c|c|c|c|c|c|c|}
\hline \multirow[t]{2}{*}{ SL. No. } & \multirow[t]{2}{*}{ Character } & \multirow[t]{2}{*}{ Mean } & \multicolumn{2}{|c|}{ Range } & \multirow{2}{*}{$\begin{array}{l}\text { GCV } \\
(\%)\end{array}$} & \multirow{2}{*}{$\begin{array}{l}\text { PCV } \\
(\%)\end{array}$} & \multirow{2}{*}{$\begin{array}{l}h^{2} \\
(\%)\end{array}$} & \multirow{2}{*}{$\begin{array}{l}\text { GAM } \\
(\%)\end{array}$} \\
\hline & & & Min & Max & & & & \\
\hline 1. & Leaf area $\left(\mathrm{cm}^{2}\right)$ & 98.32 & 67.86 & 268.71 & 27.85 & 30.94 & 81.03 & 51.64 \\
\hline 2. & Days to first flowering & 54.63 & 41.40 & 65.80 & 11.27 & 11.38 & 98.01 & 22.98 \\
\hline 3. & Days to 50 per cent flowering & 66.78 & 54.20 & 80.80 & 8.73 & 8.84 & 97.79 & 17.80 \\
\hline 4. & Days to first fruit maturity & 98.79 & 80.40 & 117.60 & 10.97 & 11.21 & 95.83 & 22.12 \\
\hline 5. & Plant height $(\mathrm{cm})$ & 61.63 & 49.28 & 90.22 & 14.19 & 15.12 & 88.14 & 27.45 \\
\hline 6. & Plant spread $(\mathrm{cm})$ & 61.88 & 41.64 & 90.52 & 19.38 & 19.62 & 97.54 & 39.42 \\
\hline 7. & Number of primary branches & 7.04 & 4.20 & 11.80 & 24.57 & 27.42 & 80.28 & 45.34 \\
\hline 8. & Fruit length $(\mathrm{cm})$ & 6.78 & 3.52 & 15.14 & 30.81 & 31.06 & 98.41 & 62.96 \\
\hline 9. & Fruit diameter $(\mathrm{cm})$ & 4.41 & 2.42 & 9.20 & 20.64 & 22.20 & 86.44 & 39.53 \\
\hline 10. & Fruit length/diameter ratio & 1.56 & 0.92 & 3.17 & 27.50 & 27.84 & 97.55 & 55.94 \\
\hline 11. & Fruit length of peduncle $(\mathrm{cm})$ & 4.06 & 2.24 & 6.88 & 15.64 & 18.11 & 74.63 & 27.84 \\
\hline 12. & Fruit size of calyx $(\mathrm{cm})$ & 2.38 & 0.72 & 4.24 & 30.04 & 32.87 & 83.52 & 56.56 \\
\hline 13. & $\begin{array}{l}\text { Fruit diameter of pistil scar } \\
(\mathrm{cm})\end{array}$ & 1.34 & 0.64 & 2.15 & 28.12 & 28.92 & 94.59 & 56.34 \\
\hline 14. & Number of fruits per cluster & 1.11 & 1.00 & 2.46 & 29.69 & 29.87 & 99.51 & 61.15 \\
\hline 15. & Number of fruits per plant & 33.38 & 13.40 & 46.00 & 21.12 & 25.46 & 68.94 & 36.15 \\
\hline 16. & Fruit weight (g) & 49.07 & 24.62 & 121.20 & 42.40 & 42.58 & 99.16 & 86.98 \\
\hline 17. & Fruit yield (q/ha) & 269.37 & $\begin{array}{l}143.4 \\
6\end{array}$ & 419.26 & 21.06 & 23.36 & 81.25 & 39.10 \\
\hline 18. & Fruit borer infestation (\%) & 23.33 & 5.74 & 44.77 & 40.05 & 48.78 & 67.41 & 67.73 \\
\hline 19. & Shoot borer infestation (\%) & 11.46 & 3.59 & 23.14 & 92.38 & 47.78 & 92.38 & 94.59 \\
\hline
\end{tabular}

GCV $=$ Genotypic coefficient of variance $\quad P C V=$ Phenotypic coefficient of variance; $h^{2}=$ Heritability (broad sense)GAM $=$ Genetic advance (per cent mean)

Thus, there is ample scope for improving these characters with direct selection. Similar findings were also reported by several investigators like Lokesh et al., (2013a), Nayak and Nagre (2013), Ramesh et al., (2013), Vidhya and Kumar (2015).

\section{References}

Abul Hasnat Muhammad Solaimana., Takashi Nishizawa., Mahmuda Khatun., and Shahabuddin Ahmad., 2015, PhysioMorphological Characterization Genetic Variability and Correlation Studies in Brinjal Genotypes of Bangladesh. Computational and Mathematical Bio., 4(1): 1-36.
Akpan, N. M., Ogbonna, P. E., Onyia, V. N., Okechukwu, E. C. and Atugwu, I. A., 2016, variability studies on ten genotypes of eggplant for growth and yield performance in south eastern Nigeria. J. Animal Plant Sci., 26(4): 1034-1041.

Anderson, E. (1957). A semi- graphical method for the analysis of complex problems. Proc. Mat. Acad. Sci., Wash. 43: 923-927.

Anonymous, 2013, Improved Cultivation Practices of Horticulture Crops (Kannada). University of Agricultural Sciences, Dharawad, pp. 173-183.

Anonymous, 2014, Integrated Horticultural Crops Management (Kannada). 
University of Horticultural Sciences, Bagalkot, pp. 65-72.

Anonymous, 2014, Indian Horticulture Database. Ministry of Agriculture, Government of Indian, New Delhi.

Arunkumar, B., Kumar, S. S. V. and Prakash, J. C., 2013, Genetic variability and divergence studies in brinjal (Solanum melongena L.)., Bioinfolet. 10(2B): 739744.

Babu, B. R. and Patil, R. V., 2004, Genetic divergence in brinjal. Vegetable Sci. 31(2): 125-128.

Babu, B. R. and Patil, R. V., 2005, Evaluation and variability studies of brinjal genotypes. Madras Agric. J., 92(7-9).

Bhaduri, P. N., 1951, Interrelationship of nontuberiferous species of Solanum with some consideration on the origin of brinjal (Solanum melongena L.). Indian $J$. of Genetics and Plant Breed., 117582.

Burton, G. W. and Devane, E. W., 1953, Estimating heritability in tall fescue (Festuca arundinaceae) from replicated clonal material. Breed. J., 45: 478-481.

Choudhary, B., 1976, Vegetables 4th ed., International book trust, New Delhi., Pp. 50-58.

Chauhan, D. V. S., 1981, Vegetable Production in India. Ramprasad and Sous, Agra.

Cockerham, C. C., 1963, Estimation of Genetic Variances. Statistical Genetics and Plant Breeding, National Academy of Science, Washington, p. 53.

Das, B., Mishra, S. N., Sahu, G. S. and Dash, S. K., 2002, Studies on variability and heritability in brinjal. The Orissa $J$. of Hort, 30(1): 54-58.

Datta, S. and Das, L., 2013, Characterization and genetic variability analysis in Capsicum annuum L. SAARC J. Agri., 11(1): 91-103.

Devi, Y. S. and Sankar, C. R., 1990, Genetic variability and correlation studies in eggplant. J. Maharashtra Agric. Univ., 15(3): 305-307.

Doshi, K.M, Bhalala, M.K. and Kathiria, K.B. 1999. Genetic variability for yield, fruit borer infestation, little leaf incidence and quality characters in brinjal., $G A U$ Res. J., 24(2): 27-30.

Falconer, D. S., 1981, Introduction to Quantitative Genetics. Ed. Oliver and Boyd, Edin berg.

Gavade R, T. and Ghadage B, A., 2015, Genetic variability, heritability and genetic advance in segregating generation of brinjal (Solanum melongena L.). BIOINFOLET., 12(1C): 325-328.

Golani, I. J., Mehta, D. R., Naliyadhara, M. V., Pandya, H. M. and Purohit, V. L. 2007. A study on genetic diversity and genetic variability in brinjal. Agric. Sci. Digest. 27(1): 22-25.

Hazra, P., Rout, A., Roy, U., Subhadeep Nath, Roy, T., Duha, R., Acharya, S. and Monda, A. K., Characterization of brinjal (Solanum mhongfna 1.) germplasm. Department of Vegetable Crops, Faculty of Horticulture, Bidhan Chandra KrishiVishwavidyalaya, West Rengal-741252

Islam, M.S. and Uddin, M. S., 2009, Genetic variation and trait relationship in the exotic and local eggplant germplasm. Bangladesh J. of Agric. Res. 34(1): 9196.

Islam, M. A, Ivy, N. A. and Mian, K. M. A., 2011, Genetic diversity in exotic eggplant (Solanum melongena L.). Libyan Agric. Res. Center J. Int. 2(1): 15-19.

Ihtizaz Hassan, Shakeel Ahmad Jatoi, Muhammad Arif, Sadar Uddin Siddiqui and Muhammad Ahson., 2015, Genetic Variability in Eggplant for AgroMorphological Traits Plant Genetic Resources Institute. Int. AgricRes. Center., 34(1): 35-40. 
Johnson, H. W., Robinson, H. P. and Comstoc, R. E., 1955, Estimation of genetic and environmental variability in soybeans. Breed. J.47: 314-318.

Kalloo, G., 1994, Veg. Breed, Panima Educational Book Agency, New Delhi, p. 41.

Karak, C., Ray, U., Akhtar, S., Naik, A. and Hazra, P., 2012, Genetic variation and character association in fruit yield components and quality characters in brinjal [Solanum melongenaL.]. University of Animal Sci. and Fishery Murshidabad, West Bengal 8(1): 86-89.

Kumar, S., Sharma, J. P. and Chopra, S., 2011, Studies on variability, heritability and genetic advance for morphological and yield traits in brinjal (Solanum melongena L.). Mysore J. of Agric. Sci. 45(1): 63-66.

Kumar, S. R., Arumugam, T. and Premalakshmi, V., 2012, Evaluation and variability studies in local types of brinjal for yield and quality (Solanum melongena L.). Electronic J. of Plant Breed. 3(4): 977-982.

Kushwah., S. and Bandhyopadhya, B. B. 2005, Variability and correlation studies in brinjal. Indian J. of Hort., 62(2): 210212.

Lokesh, B., Reddy, S. P., Reddy, R. V. S. K and Sivaraj, N. 2013a, Variability heritability and genetic advance studies in brinjal (Solanum melongena L.). Electronic J. of Plant Breed. 4(1): 10971100.

Mili, C., Bora, G. C., Das, B. and Paul, S. K., 2014, Studies on variability, heritability and genetic advance in Brinjal (Solanum melongena L.) genotypes. Direct Res. J. of Agric. and Food Sci., 2(11):192-194.

Mishra, S. N. and Mishra, R. S., 1990, Variability, heritability and genetic advance in the $\mathrm{Fl}$ generation of diallel cross in brinjal. Indian J. Hortic., 47(1):
93-96.

Mishra, S. V., Warade, S. D. and Nayakwadi, M. B. 2008. Genetic variability and heritability studies in brinjal. $J$. of Maharashtra Agric. Univ.33(2): 267268.

Mohanthy, B. 2001, Genetic variability, correlation and path coefficient studies in brinjal. Ann. of Agric. Res. 22(1): 5963.

Mohanthy, B. K. and Prusti, A. M. 2001, Diversity studies in brinjal (Solanum melongena L.). Agric. Sci. Digest.21(1): 17-20.

Mohanthy, B. K. and Prusti, A. M., 2002, Variability and selection parameters for economic characters in brinjal. The Orissa J. of Hort. 30(1): 1-4.

Moll, R. H., Salhuana, W. S. and Robinson, H. F., 1962, Heterosis and genetic diversity in variety crosses of maize. Crop Sci., 2: 197-198.

Morgado, H. S., Vaz, E. and Dias, M. J., 1992, Characterization of the (Solanum gilo) germplasm collection of CNPH/EMBRAPA. Horticultura Brasileira 10(2): 86-88.

Mukhopadhyay and Mandal., 1994, Screening of brinjal (Solanum melongena) for resistance to major insect pest. Indian $J$. Agric. Sci., 64(11): 798-803.

Muniappan, S., Saravanan, K. and Ramya, B., 2010, Studies on genetic divergence and variability for certain economic characters in Eggplant (Solanum melongena L.). Electronic J. of Plant Breed. 1(4): 462-465.

Mwirigi, P. N., Kahangi, E. M., Nyende, A. B. and Mamati, E. G. 2009, Morphological variability within the Kenyan yam (Dioscorea spp.). J. Appl. Biosci., 16: 894-901.

Naik, K. C. K., 2005, Genetic variability and divergence studies in brinjal (Solanum melongena L.). M. Sc. (Hort.) Thesis, Unvi. Agri. Sci., Dharwad (India). 
Nair, K. R. and Mukherjee, H. K., 1960, Classification of natural and plantation teak (Tectonagrandis) grown at different locations in India and Burma with respect to its physical and mechanical properties. Sankhya, 22: 120.

Naliyadhara, M.V, Golani, I.J, Mehta, D.R. and Purohit, V.L. 2007. Genetic variability, correlation co-efficient and path analysis in brinjal. The Orissa J. of Hort. 35(2): 92-96.

Narendra Singh, Gyanendra Singh, KALDA, T. S., Singh, N. and Singh, G., 1999, Genetic diversity in eggplant. IPGRI Newsletter for Asia, the pacific and oceania29: 22.

Nayak, B. R. and Nagre, P. K. 2013, Genetic variability and correlation studies in brinjal. (Solanum melongena L). Int. J. of Appl. Bio. and Pharmaceutical Tech.4(4): 211-215.

NHB Database. 2013, International Horticulture Board, New Delhi. www.nhb.gov.in

Panse, V. G. and Sukhatme, P. V., 1957, Statistical Methods for Agricultural Workers. Indian Council of Agric. Res., New Delhi, p. 145.

Patel, K. K., Sarnaik, D. A., Asati, B. S. and Tirkey, T. 2004, Studies on variability, heritability and genetic advance in brinjal (Solanum melongena L.). Agric. Sci. Digest. 24(4): 256-259.

Payal Devi, Preeti Gawde and Vijay Kumar Koshta. 2015, Screening of some brinjal cultivars for resistance to shoot and fruit borer (Leucinodes orbonalisguenee). 10(1): 247-251.

Prabhu, M., Natarajan, S. and Pugalendhi, L., 2009, Variability and heritability studies in $\mathrm{F}_{5}$ and $\mathrm{F}_{6}$ progenies of brinjal (Solanum melongena L.). American Eurasian J. of Sustainable Agric. 3(3): 306-309.

Prakash, Shivashankar, K. T. and
Ramanjimgowda, P. H., 1994, Genetic variability studies in brinjal (Solanum melongena L.). Karnataka J. Agric. Sci., 72(2): 235-237.

Pramanick, K. K., Narendrasingh and Kalda, T. S., 1994, Genetic variability in eggplant (Solanum melongena L.) Indian J. Hort., 51(1): 75-99.

Praneetha, S., Rajashree, V. and PUGALENDHI, L., 2011, Association of charecters on yield and shoot and fruit borer resistance in brinjal (Solanum melongena L.). Electronic J. of Plant Breed., 2(4):574-577.

Prasad, M., Mehta, N., Dikshit, S. N. and Nichal, S. S., 2004, Genetic variability, genetic advance and heritability in brinjal (Solanum melongena L.). The Orissa J. of Hort. 32(2): 26-29.

Ramesh Kumar S, Arumugam T., Anandakumar C. R. and Premalakshmi V., 2013, Genetic variability for quantitative and qualitative characters in Brinjal (Solanum melongena L.). Asian journal of hort., 8(39):4956-4959.

Ramesh Kumar, S., Arumugam T and Ulaganathan. V., 2016, Genetic diversity in eggplant germplasm by principal component analysis. SABRAO J. of Breed. and Geneti. 48(2) 162-17.

Rashid Khan and Y.V. Singh., 2014, Germplasm characterization in eggplant (Solanum melongena L.) 9(2):356-359.

Ravinder Kumar, Gupta, S. S., Narendra Singh. and Anil Chandra., 2000, Evaluation of eggplant (Solanum melongena L.) germplasm under subtropical condition. Capsicum and eggplant News letter., 19: 115-118.

Robinson, H. F., Comstock, R. E. and Harvey, P. M. 1949, Estimates of heritability and degree of dominance in corn. Agron. J. 41: 353-359.

Sabeena, F. A., Mehta, N., Ansari, S. and Gavel, J. P. 2011, Variability studies in brinjal (Solanum melongena L) in 
Chattisgarh plains. Electronic $J$. of Plant Breed. 2(2): 275-281.

Sao, A. and Mehta, N., 2009, Genetic studies for fruit yield and its components in brinjal (Solanum melongena L.). The Orissa J. Hort., 37(1): 40-43.

Senapati, N., Mishra, H. N., Bhoi, M. K., Dash, S. K. and Prasad, G., 2009, Genetic variability and divergence studies in brinjal (Solanum melongena L.). Veg. Sci. 36(2): 150-154.

Sharma, T. V. R. S. and Swaroop, K., 2000, Genetic variability and character association in brinjal (Solanum melongena L.). Indian J. of Hort57(1): 59-65.

Shekar, K. C., Ashok, P. and Shashikala, K., 2012, Studies on heritability and multivariate analyses in brinjal (Solanum melongena L.). Vegetable crops Resbulletin, 76:79-88.

Sherly, J. and Shanthi, A., 2008, Variability, heritability and genetic advance in brinjal (Solanum melongena L.). The Orissa J. of Hort. 36(2): 24-28.

Shinde, K. G., Birajdar, U. M., Bhalekar, M. N. and Patil, B. T., 2012, Genetic divergence in brinjal (Solanum melongena L.). Vegetable Sci. 39(1): 103-104.

Singh, A. K. and Singh, A., 2001, Correlation and path coefficient analysis of some quantitative traits in brinjal (Solanum melongena L). Crop Res. 22(3): 499502.

Singh, O. and Kumar, J., 2005, Variability, heritability and genetic advance in brinjal. Indian J. of Hort., 62(3): 265267.

Singh, P. K. and Gopalakrishnan, T. R., 1999, Variability and heritability estimates in brinjal (Solanum melongena L.). South Indian Hort. 47(1-6): 174-178.

Suyambhulingam, C. and Jobarani, W., 1978, Genetic divergence in medium duration rice (Oryza sativa L.). Madras Agric. J., 65: 56-58.

Vadivel, E. and BABU, J. R. K., 1993, Variability and heritability in segregating generation of egg plant. Madras Agricultural Journal, 8(12): 670-672.

Vadivel, E. and BAPU, J. R. K., 1988, Evaluation and documentation of eggplant germplasm. Capsicum news letter 7(80).

Vandana Yadav, Nandan Mehta, SMITA B, Rangare and Eshu Sahu., 2014, Variability and Heritability Estimates in the Germplasm Collection of Egg Plant (Solanum melongena L.) Dept. of Horticulture, IGKV, Raipur (C.G.) India. Trends in Bio. Sci., 7(12)3482: 342-369.

Vavilov, N. I., 1926, Studies on the origin of cultivated plants. Bull. Appl. Bot., 16: 2.

Vidhy, A. and Kumar, n., 2015 Genetic variability studies in Brinjal (Solanum melongena) for fruit yield and quality. Electronic J. of Plant Breed, 6(3): 668671

\section{How to cite this article:}

Jyoti P. Jirankali, Nikhila Reddy, S. Gangaprasad and Manohara, S.N. 2019. Genetic Variability for Quantitative and Qualitative Characters in Brinjal (Solanum melongena L.). Int.J.Curr.Microbiol.App.Sci. 8(03): 476-484. doi: https://doi.org/10.20546/ijcmas.2019.803.060 